\title{
Employer Control of Employee Behaviour Through Social Media
}

\author{
Sarah Hook and Sandy Noakes \\ Western Sydney University, Sydney, Australia
}

\begin{abstract}
When once individuals could 'clock off' for the day and retreat into private spaces, these private activities are increasingly prone to being recorded, tagged and shared and brought to the attention of an individual's employer. The unavoidable necessity for people to engage with each other online has blurred the boundaries between work life and private life, meaning that employers increasingly seek to control what employees do and say online, requiring individuals to carefully modify their behaviour in once private domains. As individuals become inured to the realities of being tracked and mined, the resigned cynicism of the situation is creating a culture in which freedom to 'be yourself' is undermined. This paper will explore examples of individuals who have faced consequences at work for their online behaviour in what once would have been considered their private domain. Using surveillance theory, it will seek to ask whether such a gap in the legal and regulatory sphere is at risk of submerging the individual into a docile workforce that is never 'off the clock'.
\end{abstract}

Keywords: Surveillance; social media; employment; observation; examination; privacy.

\section{Introduction}

In 1935, Hubert O'Donnell, a porter with the Department of Railways, was charged with manslaughter. ${ }^{1}$ When he advised his employer, he was 'relieved from duty' unpaid for six months. The charge did not relate to his employment. He was ultimately acquitted, and successfully sued for back pay on his return to work. The High Court found he had not been validly suspended from duty under the Government Railways Act 1912-1930 (NSW), which permitted the disciplining of employees, including suspension for 'misconduct'. The High Court held that being charged with a criminal offence did not constitute misconduct. In his judgment, Latham CJ indicated there is a distinction between 'misconduct as a citizen' and 'misconduct as an employee'. ${ }^{2}$

The advent of social media (SM) means it is no longer possible to clearly distinguish between our conduct as employees and citizens. Increasingly, employers seek to control what employees do and say as digital citizens on SM outside work to protect themselves from reputational damage. Media reports concerning the Australian Public Service Social Media Policy in 2017, ${ }^{3}$ the recent new draconian SM policy proposed for journalists ${ }^{4}$ and the Australian Rugby Union's dispute with Israel Folau ${ }^{5}$ have

\footnotetext{
${ }^{1}$ Commissioner of Railways (NSW) v O'Donnell. 1938. 60 CLR 681.

${ }^{2}$ Commissioner of Railways (NSW) v O'Donnell. 1938. 60 CLR 681, 689.

${ }^{3}$ McIlroy, "Australian Public Service Commission Social Media Guidance Angers Opposition and Activists."

${ }^{4}$ Meade, "'Don't Say Anything Stupid': Social Media Minefield for Journalists and Nine Newspapers."

${ }^{5}$ Robinson, "Rich New Contract Comes at a Cost for Israel Folau.”; Decent, "Rugby Australia Set to Sack Israel Folau for Anti-Gay Social Media Post."; Crowden, "Why Destructive, Divisive Folau could no Longer be the Face of Rugby."; Decent, "Folau Teammates 'Like' Anti-Gay Post as Sponsor Qantas Backs RA Action.”; The Roar, "Israel Folau Issued Breach Notice, Has 48 Hours to Respond.”; Giles, "Rugby Australia Terminates Israel Folau's Contract."; Mark, "Israel Folau to Take Rugby Australia to Fair Work Commission over Contract Termination."; Mark, "Israel Folau Says He Has a "Mission to Spread the Word of God as He Tries to Get His Job Back."
}

This work is licensed under a Creative Commons Attribution 4.0 International Licence. As an open access journal, articles are free to use with proper attribution. ISSN: 2652-4074 (Online) 
highlighted the extent of an employer's right to control employee behaviour on SM, particularly where that conduct may not be directly related to the employee's job and occurs when the employee is 'off the clock'.

While the regulation of employee behaviour on SM has been well canvassed in the academic literature, this work has focused on comparative studies treating this issue in different jurisdictions, ${ }^{6}$ or the regulation of employer access to information about employee behaviour on SM as an issue of employee privacy. ${ }^{7}$ To date, doctrinal analysis of the Australian case law on this issue has tended not to differentiate between the different types of employee behaviour on SM that employers seek to control. There have also been limited attempts to apply theoretical perspectives to regulating this behaviour. ${ }^{8}$

This article seeks to categorise the current Australian case law based on the common types of employee behaviour on SM, to determine if there is any consistency in the judgments. The analysis is limited to a discussion of 'out of hours' employee behaviour on SM, that is, behaviour or comment that does not occur while the employee is at work and is not using the employer's technology. It divides these cases into three categories: first, where the employee makes disparaging remarks about their employer or complains about their employment on SM (Category 1), second, where an employee engages in bullying, harassing or intimidating conduct towards other employees on SM (Category 2) and third, where an employee's conduct on SM may have no direct relationship to their employment but may damage the employer's interests and reputation if the employee's association with the employer is known (Category 3). Regarding Category 1 and 2-type conduct, we argue an employer has a legitimate interest in controlling employee behaviour on SM. Concerning Category 3 behaviour, we argue it is more difficult for an employer to demonstrate a connection between employee behaviour and the employer's interests unless it is accepted that all employees have a duty at all times to protect their employer's reputation. This article focuses on the lawfulness of employer control of employee conduct on SM in Category 3 cases, particularly via the use of SM policies.

This article will explore these issues by terming the employer's ability to control online personal spaces as a form of surveillance. Surveillance theory is then engaged with in Part 1 to highlight how such monitoring affects individual behaviour. The norms imposed on people are norms that the employers, rather than society, observe as important to their brand but which can change depending on marketing. Foucault argues that the transformation through discipline of 'docile bodies' is created by the processes of observational hierarchy, normalising judgement, and examination. All three processes are performed through employer surveillance with the employer's norms - articulated in SM policies - being the method of discipline.

Part 2 is an in-depth exploration of disputes in case law. It considers how speech or behaviour that an employer does not feel meets with their 'brand' may be used to control an employee by the threat of dismissal. It also briefly examines reasons why the authors consider the General Protections (GP) provisions of the Fair Work Act 2009 (Cth) are unlikely to assist an employee who wishes to challenge employer control of Category 3 conduct on SM.

We argue for a test of 'proportionality' when assessing the validity of a SM policy, and for objectively assessing the effect of Category 3 employee behaviour when an employer seeks to enforce a SM policy against an employee. By ensuring the courts consistently refute the idea of employers being able to exercise normalising judgement and examination of such conduct, we can avoid developing 'docile bodies' and ameliorating private domains.

Our central thesis is that SM policies or employer directions seeking to control Category 3 employee behaviour on SM are an unreasonable form of employer surveillance, and extend beyond what the law should consider a lawful and reasonable direction by an employer to an employee.

\footnotetext{
${ }^{6}$ See, for example: O'Rourke, “Old Wine in New Bottles? Regulating Employee Social Media Use through Termination of Employment Law." Thornthwaite, "Chilling Times: Social Media Policies, Labour Law and Employment Relations.” Reitz, Social Media and Employment Law: An International Survey.

${ }^{7}$ See, for example: Brown, "Privacy Concerns over Employer Access to Employee Social Media."; Thornthwaite, "Social Media and Dismissal: Towards a Reasonable Expectation of Privacy?"; Forsyth, "A Thin Wall of Privacy Protection, with Gaps and Cracks: Regulation of Employees' Personal Information and Workplace Privacy in Australia."; Raper, "Recent Privacy Considerations Arising in the Workplace: Social Media and Limitations on Collection and use by Employers of Employee Generated Content."

${ }^{8}$ For example, see Brown, "Privacy Concerns over Employer Access to Employee Social Media," McDonald, "Social Media(tion) and the Reshaping of Public/Private Boundaries in Employment Relations."
} 


\section{Part 1: Surveillance Theory}

'Man was born free, and he is everywhere in chains'9

The issue of employers watching employees in personal spaces on SM is a surveillance, rather than technology, issue. While technology may provide the tools for surveillance, it is only through examining the power relationships underlying this technology use that the ramifications of employer surveillance of SM can be explored. Surveillance theory enables us to study the effect employer surveillance has on the workforce and society more generally. When surveillance bleeds into private spheres, left unchecked, it slowly becomes entrenched as a cultural norm, making it harder to resist. As the law falls out of pace with technology and governance over this space, employees become inured to such surveillance, and gradually it becomes accepted practice. Using surveillance theory, we can observe its effects as 'malleable docile bodies' are formed. In other words, the new normal would be an inability to engage in public discourse without the employer's brand or values influencing how we conduct our private speech and behaviour.

For employers, the tools used to monitor employees may be a simple SM search or algorithms that monitor employee speech. It may be as straightforward as the employee being tagged in a Twitter post, for a Facebook post to be forwarded to an employer or an employee being recorded when drunk at a party and posted on Instagram that is shared with a workplace friend. Whether technologies are used properly or improperly does not define whether the employer's actions can be termed surveillance, nor does the proactive or reactionary use of the tools. Despite the precision or use of the technology, what is most important is the employee's knowledge of the employer's constant observation and the fear of workplace repercussions for speech or acts done away from work. It is this constant observation and normative judgement that subsequently follows that forms the training of the 'malleable docile body' that Michel Foucault warned us about. ${ }^{10}$ The role of law then becomes about how people can be protected — not from technology — but from the power imbalance and ramifications of surveillance. Employees may not be able to evade surveillance, but to be able to participate in a personal life, they need to feel safe from ramifications for their employment security.

The relationship between surveillance capitalism and law is complex and tied in with political economy. Historically, law was viewed as a protector against the emerging labour market. ${ }^{11}$ As the market transformed into a regime of informational capitalism, the law has been 're-optimised'. ${ }^{12}$ Shoshana Zuboff argued that the pervasive data-fication of everyday life is a problem not simply of privacy or monopoly but where law is now used as a tool by business. ${ }^{13}$ The law is not protective now but rather the means through which expressions of economic rationality become legitimised.

What has this to do with the workplace? Employers harness legal regulation to establish control through using their SM policies and an employee's contractual duties. The line between work life and non-work life is ultimately blurred through technology use and enforced through legal tools to assert more control over behaviour.

As argued by Patricia Sanchez Abril et al., SM is a forum for individuals to express themselves. ${ }^{14}$ Social interaction online is increasingly becoming the way individuals connect with each other in what were once private gatherings. With the ability to share opinions more broadly comes the trade-off of private opinions being made public. The study by Abril et al. shows that while people may recognise their vulnerability by sharing opinions online, they are reluctant to sacrifice the participation and often unable to use tools to shield their performances: 'Millennials rely on others, including employers, to refrain from judging across contexts'. ${ }^{15}$ As the cases below demonstrate, this expectation may be misplaced. It is when this expectation is eroded that we observe the chilling effect of employer surveillance in which the 'tools for self-expression turn oppressive in the absence of normative, technological and legal controls'. ${ }^{16}$ The more that SM policies become standard practice, the more authority they gain, leading to normalising employer surveillance of out of work conduct, making it difficult to dislodge and for the law to regulate. It also provides non-state actors the power to determine behavioural norms outside the criminal justice system without

\footnotetext{
${ }^{9}$ Rousseau, The Social Contract, 49.

${ }^{10}$ Foucault, Discipline \& Punish, this term is discussed below.

${ }^{11}$ Deakin, "Legal Institutionalism: Capitalism and the Constitutive Role of Law."

${ }^{12}$ Zuboff, The Age of Surveillance Capitalism: The Fight for a Human Future at the New Frontier of Power, 139.

${ }^{13}$ Zuboff, The Age of Surveillance Capitalism: The Fight for a Human Future at the New Frontier of Power, 194.

${ }^{14}$ Abril, "Blurred Boundaries: Social Media Privacy and the Twenty-First-Century Employee," 64.

${ }^{15}$ Abril, "Blurred Boundaries: Social Media Privacy and the Twenty-First-Century Employee," 64.

${ }^{16}$ Abril, "Blurred Boundaries: Social Media Privacy and the Twenty-First-Century Employee," 64.
} 
the appeal and recourse an individual would normally have when dealing with a state actor: '[T]he use of social media destabilises private/public boundaries and opens up or facilitates new terrains on which contestation may arise'. ${ }^{17}$

Theories on the social conditions that enhance and motivate surveillance have been a popular critical pursuit for decades. These theories aid in interpreting both employer motivation and the effects of surveillance, such as the erosion of personal spaces and conformity of behaviour. Such behaviour modification has a real effect on shaping 'docile bodies', what Foucault terms 'normation', ${ }^{18}$ and profound effects on democracy and free speech. The power structures that create and maintain those norms also need to be addressed to show why the regulatory gap is such a serious issue for all citizens. It is argued by McDonald and Thompson that this is not a new direction for employers. ${ }^{19}$ They noted early factory employers concerned with sexual, drinking and spending habits of their employees and later examples, such as Ford mandating codes of conduct on how employees spent their evenings to participate in profit-sharing. ${ }^{20}$ However, they argued that these examples did not cross the public/personal boundary in the same way that SM does by providing access to an employee's social identity in ways never seen before. ${ }^{21}$

Jeremy Bentham's Panopticon ${ }^{22}$ has almost become a symbol for the field of surveillance research. ${ }^{23}$ For Bentham, a utilitarian, securing happiness to the greatest number of people consisted of people conforming to the ideal society by the omnipresent watchman. ${ }^{24}$ He believed such surveillance would decrease the need for punitive punishment ${ }^{25}$ — when we are being watched, we act better, leading to an ideal society. However, when it is the employer watching, we have moved the watchman from the state to private enterprise. It is the employer's 'brand' that then determines what the 'ideal' is, not for the benefit of society but for the benefit of the company and how it is viewed in the marketplace.

We mostly view Bentham through Foucault's criticism, where this idea of a non-punitive system is critically analysed for its relationship with discipline, describing the panopticon as a 'mechanism of power'. ${ }^{26}$ According to Foucault, there are three processes involved in the production of docile bodies: observational hierarchy, normalising judgement, and examination. ${ }^{27}$ 'Docile bodies' are individuals who, from a form of discipline, are obedient, compliant and malleable. ${ }^{28}$ Disciplining institutions measure, document and evaluate to control and to dominate. In the employment context, we can think of published SM policies, employees being observed through their SM, an employee disciplined for an offensive tweet or drunken tagged picture and then the fear of repercussion. This then works to serve as an example to other employees. Employees are now more nervous to ensure their SM is 'clean', politically correct and, depending on the values of the company, science neutral or progressive.

Foucault talked about individuals passing through enclosed spaces: ${ }^{29}$ the family, school, factory and, most notably, prison. These enclosed environments are termed societies of control. Enclosures are moulds but also, traditionally, have an exit point. The information economy means there is a danger of limitlessly postponing the exit of societies of control, in which '[i]ndividuals have become 'dividuals' and masses, samples, data, markets or "banks". ${ }^{30}$ In Foucault's analysis, the production of the docile body is under the control of its possessor and in alignment with norms and subtle forms of regulation that are learned and developed through training rather than through the application of external force.

\footnotetext{
${ }^{17}$ McDonald, "Social Media(tion) and the Reshaping of Public/Private Boundaries in Employment Relations," 77.

${ }^{18}$ Foucault, Discipline \& Punish, 184.

${ }^{19}$ McDonald, "Social Media(tion) and the Reshaping of Public/Private Boundaries in Employment Relations."

${ }^{20}$ McDonald,"Social Media(tion) and the Reshaping of Public/Private Boundaries in Employment Relations."

${ }^{21}$ McDonald, "Social Media(tion) and the Reshaping of Public/Private Boundaries in Employment Relations."

22 Bentham, An Introduction to the Principles of Morals and Legislation.

${ }^{23}$ Galic, "Bethan, Deleuze and Beyond: An Overview of Surveillance Theories from the Panopticon to Participation,"11. Many critics now call for a method that moves beyond this pivotal point in acknowledging the use of surveillance technology in modelling behaviour. For example, see the works of Anthony Giddens, Christopher Dandeker, James Rule and Sean Hier.

${ }^{24}$ Such principles inform modern day issues of surveillance, particularly the modifying of behaviour. Surveillance theory from Bentham and Foucault onwards (e.g., Gilles Deleuze and Felix Guattari) examines surveillance in terms of control societies and surveillance capitalism (e.g., Shoshana Zuboff). Contemporary surveillance theory mainly uses these theories as a starting point regarding emerging technologies (e.g., see Kevin Haggerty, David Murakami Wood and David Lyons).

${ }^{25}$ Foucault, Discipline \& Punish, 201.

${ }^{26}$ Foucault, Discipline \& Punish, 205.

${ }^{27}$ Allmer, Towards a Critical Theory of Surveillance in Informational Capitalism, 21.

${ }^{28}$ Allmer, Towards a Critical Theory of Surveillance in Informational Capitalism, 21.

${ }^{29}$ Foucault, Discipline \& Punish, 142.

${ }^{30}$ Deleuze, "Postscript on the Societies of Control."
} 
The modelling of out of work behaviour should not be the concern of the employer but of the state. Employers have the power over the means of production and now also over information, creating a powerful relationship of control. ${ }^{31}$ Using concepts of reputational damage and 'legitimate business interests', ${ }^{32}$ an employer seeks to claim both the employee's labour and their online social identity, subjecting them to 'moral management'. ${ }^{33}$ The tension is furthered by the effect SM can have on an employer's reputation. Employees owe their employers a duty of fidelity and loyalty. ${ }^{34}$ Previously, activities outside work may have had little influence on a business' interests; an employee's political views or social behaviour was separate to the business. SM profiles mean an employee's workplace is readily identified-people can easily and publicly condemn an employer for employing someone who acts or speaks in a particular way on SM, even if it has nothing to do with their employment. ${ }^{35}$ This can affect the employer's reputation and business interests. Regarding the tension between the employer's right to protect their brand image and a citizen's right to a personal life, surveillance theory reminds us that the power here is imbalanced, and more is needed to protect the citizen from the ordering gaze of the employer.

Surveillance is a well-documented management tool ${ }^{36}$ However, the panopticon model, via employer control of employee behaviour on SM, can shape an employee's personal life and behaviour in the community at large. This is worrying, as an employee would then need to model their social behaviour on standards dictated by their employer rather than society. To resist the effectiveness of this technique, employees need to feel safe from examination of their personal lives. While it may not be possible to stem observation and surveillance, the model can be disrupted if the normalising of the employer's judgement and examination is disrupted. Disruption occurs if employees know that despite overreaching SM policies, such examination cannot influence their ability to earn a wage. Thus, employees will feel safe to express themselves after work despite the employer's omnipresent gaze. We argue this can be done through an acceptance by the courts and tribunals that the employee does not have a duty to protect the employer's reputation beyond the scope of the employee's duties and is free to have a non-work persona.

\section{Part 2: Disputes In The Australian Case Law}

In Australia, disputes about employee behaviour on SM are aired under the federal unfair dismissal jurisdiction under the Fair Work Act 2009 (Cth). ${ }^{37}$ Under the Act, in determining whether a dismissal is harsh, unjust or unreasonable, the Fair Work Commission (FWC) must consider matters such as whether there was a valid reason for the dismissal related to capacity or conduct, notification, opportunity to respond, unreasonable refusal to have a support person, and whether the person had been warned when dealing with unsatisfactory performance. The FWC also considers the size of the business in such procedures, the absence of human resources management, and any other matters they may consider relevant. ${ }^{38}$

In numerous decisions dating back to 2009, the FWC has examined whether an employee's conduct on SM constitutes a 'valid reason'-'sound, defensible or well founded' - for dismissal. ${ }^{39}$ While a breach of the employment contract by the employee constituting serious misconduct and therefore a repudiation of the employment contract will constitute a valid reason, the employee's conduct does not have to amount to a contractual repudiation for the employer to have a valid reason for dismissal. ${ }^{40}$

\footnotetext{
${ }^{31}$ Thompson refutes the idea that surveillance as managerial practice is as extreme as critics argue, but only regarding 'at work' surveillance; Thompson, "Fantasy Island: A Labour Process Critique of the 'Age of Surveillance," There are others who argue that because surveillance is also applicable to the powerful, it is a great leveller of power rather than a tool of oppression (e.g., see Haggerty and Ericson, "The Surveillant Assemblage."

${ }^{32}$ Ghoshray, "Employer Surveillance Versus Employer Privacy: The New Reality of Social Media and Workplace Privacy,” 601.

${ }^{33}$ Sewell, 'Organization, employees and surveillance," 306.

${ }^{34}$ Robb v Green. 1895. 2 QB 315.

${ }^{35} \mathrm{See}$, for example, this tactic being used by some feminists to call out misogynistic comments or behaviour of people online: Lieu,

"Australian Man Gets Himself Fired After Making Sexist Comments on Facebook."

${ }^{36}$ Henderson, "Under the Employer's Eye: Electronic Monitoring and Surveillance in Australian Workplaces."

37 The FWC jurisdiction has existed in different forms since the introduction of the Industrial Relations Reform Act 1993 (Cth). Similarly, in the United Kingdom, disputes about employee behaviour on SM have also arisen in the context of its unfair dismissal regime under the Employment Rights Act 1996 (UK). See O'Rourke, "Old Wine in New Bottles?"; Thornthwaite, "Social Media and Dismissal." In the USA, the dominance of the employment at will doctrine means there is less protection for employees terminated for their behaviour on SM. See O'Rourke, "Old Wine in New Bottles?"; Lam, "Social Dilemmas in the Employment Context." However, ss 7 and 8 of the National Labor Relations Act 1935, 29 U.S.C. $\S \S 151-169$ permit employees to communicate about matters of concern at work and prevent employers restricting this right, and may protect employee comment on SM about such matters: See Thornthwaite, "Chilling Times: Social Media Policies, Labour Law and Employment Relations”; O’Rourke., 'Old Wine in New Bottles?"

${ }^{38}$ Fair Work Act 2009 (Cth) s 387.

${ }^{39}$ Selvachandran v Peterson Plastics. 1995. 62 IR 371.

${ }^{40}$ Selvachandran v Peterson Plastics. 1995. 62 IR 371; Potter v WorkCover Corporation. 2004. 133 IR 458; Annetta v Ansett Australia. 2000. 98 IR 233.
} 
However, in most cases, to determine whether there is a valid reason for dismissal, the FWC needs to consider whether the employee's conduct on SM is incompatible with their duties as an employee. This usually necessitates the Commission identifying a contractual obligation owed by the employee to the employer.

Often when employer control of employee behaviour on SM is discussed in the literature, there is little attempt to categorise the different types of behaviour, some of which are more closely linked to employment than others. In Australia, it appears these cases fall into three categories.

\section{Category 1: 'Badmouthing' The Employer}

The first category of case is where the employee makes disparaging remarks about their employer or clients or complains about their employment on SM. All employees have an implied contractual duty of fidelity and loyalty, precluding employees making disparaging remarks about their employer. ${ }^{41}$ While early FWC decisions were reasonably forgiving of such behaviour, sometimes characterising it as 'silly', but not necessarily damaging to the employer's business, ${ }^{42}$ or likening it to a group of friends 'letting off steam' in a pub or café after work, ${ }^{43}$ others have emphasised the public nature of these comments and queried whether they can be compared to 'pub grumbling' ${ }^{44}$ It appears the FWC may protect legitimate comment about working conditions on $\mathrm{SM},{ }^{45}$ but is unlikely to excuse an employee's abuse or disparagement of other employees, clients, or management. ${ }^{46}$ In Category 1 cases, factors that seem relevant to whether the employee's comments on SM constitute a valid reason for dismissal include whether: the employer is identified or identifiable in the posts, ${ }^{47}$ the comments are clearly directed at the employer or relate to the employee's employment, ${ }^{48}$ the comments relate to personal matters with only a tangential connection to the workplace, ${ }^{49}$ and there is evidence the employee intended to damage or harm the employer's reputation. ${ }^{50}$ In Starr v Department of Human Services, the Commission noted that 'while as a general proposition ... employees are entitled to dislike their jobs and to say so publicly', ${ }^{1}$ they are not entitled to make disparaging remarks about clients on SM or indicate that they are embarrassed to work for their employer.

\section{Category 2: Bullying Or Harassing Other Employees}

The second category of cases is where an employee engages in bullying, harassing or intimidating conduct towards other employees on SM. Here, the decisions have been reasonably consistent - even where an employee engages in this conduct away from work, the employer has a right to discipline them. For example, in Remmert v Broken Hill Operations, an employee's derogatory comments on Facebook about a photo of a person resembling his supervisor constituted a valid reason for dismissal, even though the comments on the photo were made out of work hours. ${ }^{52}$ The FWC observed that the post was either knowingly directed at the supervisor or made knowing others would take the comment to be a reference to the supervisor. An employer's interest in controlling such behaviour stems from its potential liability at common law and under work health and safety and anti-discrimination legislation, such as the Sex Discrimination Act 1984 (Cth). ${ }^{53}$ Even where the employer may not be legally liable for the employee's conduct, it is still a matter for which employee may be disciplined if it affects work relationships. ${ }^{54}$

\footnotetext{
${ }^{41}$ Byrnes v Treloar. 1997. 77 IR 332.

${ }^{42}$ Fitzgerald v Smith. 2010. 204 IR 292.

${ }^{43}$ Stutsel v Linfox Australia Pty Limited. 2011. 217 IR 28.

${ }^{44}$ Linfox Australia Pty Limited v Stutsel. 2012. 217 IR 52.

${ }^{45}$ Re Broadmeadows Disability Services. 2011. FWA 4063; Vosper v Solibrooke Pty Limited. 2016. FWC 1168; Klooger v Foodora Australia Pty Limited. 2018. FWC 6836.

${ }^{46}$ Dover-Ray v Real Insurance Pty Ltd. 2010. 204 IR 399; Campbell Qube Ports Pty Ltd. 2017. FWC 1211; Little v Credit Corp Group Limited. 2013. FWC 964.

${ }^{47}$ Fitzgerald v Smith. 2010. 204 IR 292.

${ }^{48}$ Lukazsewski v Capones Pizzeria Kyneton. 2009. AIRC 280; Somogyi v LED Technologies Pty Limited. 2017. FWC 1966.

${ }^{49}$ Wilkinson-Reed v Launtoy. 2014. FWC 644.

${ }^{50}$ Rani v Limitless Ventures Tpscas Pty Limited. 2015. FWC 6429.

${ }^{51}$ Starr v Department of Human Services. 2016. FWC 1460, 68.

${ }^{52}$ Remmert v Broken Hill Operations. 2016. FWC 6036.

${ }^{53}$ Colwell v Sydney International Container Terminals Pty Limited. 2018. FWC 174. Renton v Bendigo Health Care Group. 2017. FWC 921; Natoli v Anglican Community Services t/a Anglicare. 2018. FWC 2180; Ambrose v Moolarban Coal Operations. 2014. FWC 3899. See also Bowker; Coombe; Zwarts v DP World Melbourne Limited T/A DP World; Maritime Union of Australia, The Victorian Branch and Others. 2014. FWFCB 9227 and Roberts $v$ VIEW Launceston Pty Ltd as trustee for the VIEW Launceston Trust and Ors. 2015. FWC 6556 that indicates this behaviour may also constitute 'workplace bullying' under the Fair Work Act 2009 (Cth).

${ }^{54}$ Fussell $v$ Transport for NSW/TA Transport for NSW. 2019. FWC 1182; Little v Credit Corp. 2013. FWC 9642; O’Keefe v William Muir's Pty Limited. 2011. FWA 5311; Rombola v Rail Commissioner. 2017. FWC 194.
} 


\section{Category 3: Damage By Association}

The third category of case is the most challenging for the law. This is where an employee's conduct on SM has no direct relationship to their employment but may damage the employer's interests and reputation if the employee's association with the employer is known. This may include political comments made by employees on SM or any offensive comment or conduct by an employee that an employer fears will damage its reputation by association. For example, in early 2015, SBS dismissed one of its sports journalists, Scott McIntyre, for comments he posted in relation to ANZAC Day on his Twitter handle. ${ }^{55}$ In late 2015, the Meriton Group dismissed a maintenance manager for 'trolling' feminist writer Clementine Ford on SM. Ms Ford forwarded screenshots of his posts to his employer who then terminated his employment. ${ }^{56}$ In 2018 , the media reported about a teacher at Geelong Grammar who was being investigated by her employer for participation in a private anti-vaccination chat group. ${ }^{57}$ In mid-2018, Angela Williams, a public policy and government relations manager with Cricket Australia, was dismissed following her SM comments relating to the lack of abortion services and support provided by the Tasmanian Government. ${ }^{58}$ The dispute between footballer Israel Folau and the Australian Rugby Union relating to Folau's comments on SM concerning LGBTQI people has been well documented. ${ }^{59}$

How the law should deal with Category 3 conduct on SM is an open question in Australia. Common advice to employers appears that they may control employee behaviour on SM via a written SM policy. ${ }^{60}$ Thornthwaite's study of 15 SM policies in Australia found that almost every policy included a 'restriction on SM conduct in employees' private time' ${ }^{61}$ Indeed, while the absence of a SM policy is not fatal to an employer's defence of an unfair dismissal claim, ${ }^{62}$ the FWC appears to give weight to whether the employer had a published SM policy. ${ }^{63}$ The ambit of these SM policies contribute to the surveillance model of behaviour conformity. Once an individual knows they are being observed and that they may be subsequently judged and examined, they are then unable to participate and perform online as anything other than a brand ambassador for their employer.

This may align with Foucault's description of the collective coercion of bodies through 'correct training' ${ }^{64}$ The ordering of discipline, as described by Foucault, requires hierarchical observation. The SM policy and threat of constant surveillance meets this requirement. Just as 'the details of surveillance were specified' and 'integrated into the teaching relationship' ${ }^{65}$ concerning schooling, here the workplace sets up the construct of monitors and observes 'the uninterrupted play of calculated gazes' ${ }^{66}$

\footnotetext{
${ }^{55} \mathrm{Mr}$ McIntyre commenced a GP claim under the Fair Work Act against SBS, claiming he had been unlawfully dismissed for expressing a political opinion. This matter was resolved prior to hearing. See McIntyre v Special Broadcasting Services Corporation T/A SBS Corporation [2015] FWC 6768.

${ }^{56}$ Lieu, "Australian man gets himself fired after making sexist comment on Facebook."

57 The Age, "Minister Slams Geelong Grammar Teacher's 'Irresponsible' Anti-Vax Post."

${ }^{58}$ Ms Williams also commenced a GP claim against Cricket Australia that was also resolved out of Court. See Whitson, "Angela Williamson: Cricket Australia Sacking Saga Ends with Out-of-Court Settlement."

${ }^{59}$ See articles discussed at footnote 5. Razak, Iskhandar, "Israel Folau's Unfair Dismissal Case against Rugby Australia Set for Trial in February."

${ }^{60}$ See, for example: Rapaport, "Social Media Policies and Unfair Dismissal”; O’Rourke, “Old Wine in New Bottles?”; O'Halloran, “The Rise of e-Misconduct in the Workplace"; O'Halloran, "When Can You Dismiss an Employee for Misuse of Social Media"; Smith, "Employment Law and Social Media"; Mattson, "Expressing an Opinion on Social Media"; Moore, "Social Media Risk Management"; Bland, "Legal Risk Management of Social Media in the Workplace"; Byrnes, "Personal Expression, Professional Pain: Social Media and the Workplace"; Thinakaran, "How to Write a Social Media Policy"; Kelly, "Disciplining Employees' Out-of-Hours Behaviour"; Hebblewhite, "How to Draft an Effective Social Media Policy for your Organisation"; Cox, "Australia: Why Your Workplace Needs a Social Media Policy"; Scott, "Canada: Why Your Business Needs A Social Media Policy”; Macinnis, “Australia: No Social Media Policy?"; Lovell, "Misconduct by Social Media—a Global Perspective"; Byrnes, "Social Media Policy Legitimate for Protection of Employer Interests"; Loeb, "Canada: Social Media Use and the Workplace”; Hodgkinson, "Canada: Why Your Business Needs A Social Media Policy."

61 Thornthwaite, "Chilling Times," 343.

${ }^{62}$ Dover-Ray v Real Insurance Pty Ltd. 2010. 204 IR 399.

${ }^{63}$ Linfox Australia Pty Limited v Stutsel. 2012. 217 IR 52; Somogyi v LED Technologies Pty Limited. 2017. FWC 1966, Campbell Qube

Ports Pty Ltd. 2017. FWC 1211.

${ }^{64}$ Foucault, Discipline \& Punish, 170.

${ }^{65}$ Foucault, Discipline \& Punish, 175.

${ }^{66}$ Foucault, Discipline \& Punish, 177.
} 
It is arguable that, even where an employer has a SM policy, this should not protect the employer if the policy ventures too far into an employee's off-duty life. Pre-SM case law consistently reinforces that employees have a right to a personal life. ${ }^{67}$ However, SM means we now conduct that personal life more publicly. Australian privacy law provides limited protection to employees regarding employers accessing and using information about employee behaviour on SM. In Category 3 cases, we argue there may be some avenues available to employees whose behaviour on SM is curtailed by an employer's SM policy. We further argue that SM performance should be given the same limited connection to employment that real-world actions have in the past.

\section{GP Provisions Of The Fair Work Act}

An avenue that may be available to employees disciplined or dismissed for breaching a SM policy for comments of a political or religious nature is that this constitutes a breach by the employer of relevant state anti-discrimination legislation and/or the GP provisions of the Fair Work Act ${ }^{68}$ As discrimination in employment because of religion or political opinion is not currently unlawful under Commonwealth anti-discrimination legislation, and not all states and territories have protection against employment discrimination because of political opinion or religion, ${ }^{69}$ the authors have focused on the GP provisions of the Fair Work Act.

The GP provisions prohibit an employer taking adverse action such as dismissal against an employee for certain 'prohibited reasons', including the employee's political opinion or religion. ${ }^{70}$ Employee claims under the GP provisions involving dismissal have increased markedly in recent years. ${ }^{71}$ These provisions provide for an extensive range of remedies for employees who are dismissed for prohibited reasons. ${ }^{72}$ They also contain a reverse onus of proof, requiring the employer to prove on the balance of probabilities that the prohibited reason was not why the employer terminated the employee's employment. ${ }^{73}$

However, in Board of Bendigo Regional Institute of Technical and Further Education v Barclay, ${ }^{74}$ the High Court held that, in discharging its onus of proof, the employer may adduce evidence of its subjective intention in taking the adverse action against the employee. Thus, even where the employee is terminated for expressing a religious or political view on SM, the employer may provide evidence that its subjective reason for terminating the employee was the employee's breach of its SM policy, particularly if the employee expresses provocative or offensive views. This is reinforced by the decision in $C F M E U v B H P$ Coal Pty Limited. ${ }^{75}$ In this case, an employee was involved in a lawful picket line at BHP where he waved a sign at workers who crossed the line that read, 'No principles, SCABS no guts'. The employer terminated his employment for breaching BHP's Workplace Conduct Policy, which required 'courtesy and respect to be accorded to fellow employees', ${ }^{76}$ claiming the word 'SCAB' was offensive and the employee's actions in waving the sign were intimidating and harassing. The employee claimed the employer had breached the GP provisions that prohibit an employer terminating an employee because the employee has engaged in lawful industrial action and/or represented or advanced the views or interests of an industrial association. ${ }^{77}$ In this case, by a bare majority, ${ }^{78}$ the High Court held that it was possible to distinguish between participation in lawful industrial activity (the employee engaging in the picket) and the manner of that participation (the employee waving the sign with the word ' $\mathrm{SCAB}$ ' on it). As the trial judge had accepted the employer's evidence that it had terminated the employee for the

\footnotetext{
${ }^{67}$ Australian Tramway Employees' Association v Brisbane Tramways Company Limited. 1912. 6 CAR 34; McManus v Scott- Charlton. 1996. 70 FCR 16; Applicant v Respondent. 1998. AIRC 639; Rose v Telstra Corporation Limited. [1998] AIRC. 4 December. http://classic.austlii.edu.au/cgi-bin/sinodisp/au/cases/cth/AIRC/1998/1592.html; GrainCorp Operations v Markham. 2002. IR 253.

${ }^{68}$ See Brown, "Privacy Concerns over Employer Access to Employee Social Media." Note that employees who fall outside the coverage of the GP provisions are protected by similar provisions relating to unlawful termination of employment: see Fair Work Act 2009 (Cth) s 772 ; McIntyre v Special Broadcasting Services Corporation T/A SBS Corporation. 2015. FWC 6768. This is the route being taken by Israel Folau against the ARU.

${ }^{69}$ For a table setting out the coverage of state and territory anti-discrimination legislation in employment, see Stewart, Stewart's Guide to Employment Law, 319. At the time of writing, the federal government had announced plans to introduce religious freedom laws that would, among other things, protect employees disciplined for expressing religious beliefs (e.g. Koziol, "Folau's Law")

${ }^{70}$ Fair Work Act 2009 (Cth) s 351.

${ }^{71}$ See Fair Work Commission, “Annual Report 2017-2018.”

${ }^{72}$ Fair Work Act 2009 (Cth) s 545, which provides that the remedies can include injunction or declaration, compensation and reinstatement of a dismissed employee.

${ }^{73}$ Fair Work Act 2009 (Cth) ss 360, 361.

74 2012. 248 CLR 500.

75 2014. 253 CLR 243

${ }^{76}$ CFMEU v BHP Coal Pty Limited. 2014. 253 CLR 243, 248.

${ }^{77}$ Fair Work Act 2009 (Cth) ss 347(b)(iii), 347(b)(v).

${ }^{78}$ French CJ, Kiefel and Gaegler JJ (Hayne and Crennan JJ dissenting).
} 
expression on the sign, this meant the employer had not terminated the employee by reason of him participating in lawful industrial activity. By analogy, employers who dismiss employees for expressing religious or political comments on SM could argue the dismissal is not due to the employees holding those beliefs but the manner of their expression.

\section{Challenge To Legal Status Of SM Policy As Contractual Term}

Further consideration needs to be given to the legal status of employer SM policies, particularly the nature of the employee's legal obligation to observe a SM policy. If a SM policy can be challenged, then the discipline process described by Foucault is disrupted. Disciplinary punishment, according to Foucault, must be essentially corrective. ${ }^{79}$ Thus, for a SM policy to produce docile bodies, there must be penalty for non-compliance. If a SM policy is not enforceable, then this curtails the normalising judgement and examination required to produce docile bodies. The existence of the SM policy may still contribute to Foucault's observational hierarchy. However, an unenforceable rule is unlikely to modify an employee's behaviour to the same extent because non-observance of the SM policy cannot be punished.

\section{SM Policy As Express Contractual Term}

There are two ways in which a SM policy may have contractual force. First, the policy may be incorporated into the employee's contract of employment (COE) and become an express contractual term. Where this occurs, breach of the policy will be a breach of the COE, allowing the employer to argue there is a valid reason for the employee's dismissal. The test for whether a workplace policy has been expressly incorporated into the COE has been developed in recent years in Australia, mainly in the context of whether the policies are binding on employers. ${ }^{80}$ In determining whether the terms of the policy have been expressly incorporated into the contract, the courts apply an objective test: 'What matters is what each party by words and conduct would have led a reasonable person in the position of the other party to believe'. ${ }^{81}$

In determining whether these terms have been expressly incorporated into the COE and are contractually binding, the courts have considered factors such as whether the language of the policy is 'promissory' in nature, ${ }^{82}$ the mutuality of the obligations ${ }^{83}$ and whether the terms of the policy are similar to those that would normally be found in a COE. ${ }^{84} \mathrm{Courts}$ have also considered highly persuasive whether employees are given access to the policy prior to commencing employment, and required to sign a document acknowledging that they had read it. ${ }^{85}$ In Royal Bank of Scotland, the fact that the employer's redundancy policy was a closed policy and unknown to the employee was fatal to his claim that the redundancy policy had been incorporated into his COE and was contractually binding on the employer. ${ }^{86}$

Another issue concerning whether workplace policies are contractually binding is the extent to which they may be unilaterally varied by the employer. Often an employer will expressly reserve the right to vary its workplace policies. While both Riverwood and Farstad indicate that an express right by the employer to unilaterally vary a policy will not prevent the policy having contractual force, ${ }^{87}$ this has been doubted in Wittenberg. ${ }^{88}$ In Wittenberg, in obiter, Buchanan $\mathrm{J}$ observed that the correct approach to characterising a workplace policy that gave an employer discretion to vary the policy was that the policy was not 'a mutual statement of contractual rights and obligations' ${ }^{89}$ This lack of mutuality would then mean the policy was not contractual in nature.

\footnotetext{
${ }^{79}$ Foucault, Discipline \& Punish, 179.

${ }^{80}$ See, for example Riverwood International Pty Ltd v McCormick. 2000. 177 ALR 193; Goldman Sachs JB Were Services Pty Ltd v Nikolich. 2007. 163 FCR 62; Romero v Farstad Shipping (Indian Pacific) Pty Limited. 2014. 231 FCR 403; McKeith v Royal Bank of Scotland. 2016. 92 NSWLR 326; Westpac Banking Corporation v Wittenberg. 2016. 242 FCR 505; Gramotnev v Queensland University of Technology. 2015. 251 IR 448

${ }^{81}$ Toll (FGCT) Pty Limited v Alphapharm Pty Limited. 2004. 219 CLR 165, 179 [40].

${ }^{82}$ Riverwood International Pty Ltd v McCormick. 2000. 177 ALR 193; Goldman Sachs JB Were Services Pty Ltd v Nikolich. 2007.163 FCR 62; Romero v Farstad Shipping (Indian Pacific) Pty Limited. 2014. 231 FCR 403.

${ }^{83}$ Riverwood International Pty Ltd v McCormick. 2000. 177 ALR 193; Goldman Sachs JB Were Services Pty Ltd v Nikolich. 2007. 163

FCR 62; Romero v Farstad Shipping (Indian Pacific) Pty Limited. 2014. 231 FCR 403.

${ }^{84}$ Goldman Sachs JB Were Services Pty Ltd v Nikolich. 2007. 163 FCR 62; Romero v Farstad Shipping (Indian Pacific) Pty Limited. 2014.

231 FCR 403; McKeith v Royal Bank of Scotland. 2016. 92 NSWLR 326.

${ }^{85}$ Goldman Sachs JB Were Services Pty Ltd v Nikolich. 2007. 163 FCR 62; Romero v Farstad Shipping (Indian Pacific) Pty Limited. 2014. 231 FCR 403.

${ }^{86}$ McKeith v Royal Bank of Scotland. 2016. 92 NSWLR 326, 360 [126], per Tobias JJ, Emmett AJA and McFarlan JA agreeing.

${ }^{87}$ Romero v Farstad Shipping (Indian Pacific) Pty Limited. 2014. 231 FCR 403 [59]; Riverwood International Pty Ltd v McCormick. 2000. 177 ALR 193, [111] per North J; [150], [152] per Mansfield J.

${ }^{88}$ Westpac Banking Corporation v Wittenberg. 2016. 242 FCR 505527 [112].

${ }^{89}$ Westpac Banking Corporation v Wittenberg. 2016. 242 FCR 505527 [112].
} 
Based on these tests, it is unlikely that a SM policy introduced after an employee commences work with the employer would be contractually binding on the employee as an express term of the COE. ${ }^{90}$ Additionally, as it is likely an employer would seek to reserve the right to unilaterally vary its policies, this also may be inimical to the SM policy having effect as an express term of the employee's COE. Finally, after the decisions in Riverwood and Nikolich, employers were commonly advised to ensure that employment contracts and/or their workplace policies contained an express term that the policies did not form part of the COE. ${ }^{91}$ Such policies are unlikely to be binding as an express contractual term. ${ }^{92}$

\section{SM Policy As Lawful And Reasonable Direction}

However, a SM policy does not have to be expressly incorporated into a COE to be binding, but can simply be a manifestation of an employer's right to give lawful and reasonable directions to its employees. Potter $v$ WorkCover Corp is authority that an employer is entitled through its policies to give such directions. ${ }^{93}$

All employees have an implied duty at common law to obey lawful and reasonable directions. ${ }^{94}$ A lawful direction will be one that involves no illegality and is within the scope of the employment contract. In King v Catholic Education Office ('King'), the Full Bench of the FWC observed that:

The scope of employment is a somewhat broader conception than just the course of the performance of duties under the employment contract ... the scope of the employment of an employee [is] determined by the nature of the work the employee is engaged to do, the terms of the contract, and customary practices or the course of dealings between the parties..$^{95}$

However, $R v$ Darling Island Stevedoring establishes that a direction must also be reasonable:

If a command relates to the subject matter of the employment and involves no illegality, the obligation of the servant to obey it depends at common law upon its being reasonable. ${ }^{96}$

The test for whether a workplace policy constitutes a lawful and reasonable direction comes from Woolworths $v$ Brown. ${ }^{97}$ In this case, Mr Brown was dismissed for refusing to remove his eyebrow ring when working as a butcher for Woolworths, contravening Woolworths' policies relating to the wearing of jewellery and personal hygiene. The Australian Industrial Relations Commission held that, for an employer's policy to constitute a lawful and reasonable direction, the policy must be 'rationally related to the business of the employer' ${ }^{98}$ In this case, the policy was considered a lawful and reasonable direction concluding that the policy was 'rationally related to the business of (Woolworths) and (was) directed at matters affecting the work of employees serving customers or involved in the handling and preparation of food'. ${ }^{9}$

Regarding employer policies that seek to control employee behaviour out of hours, in King, the Full Bench of the FWC stated that ' $(\mathrm{t})$ he circumstances in which an employer may make lawful directions in respect of the off-work activities of employees will ... usually be very limited', ${ }^{100}$ and that what is required is a 'significant connection with or effect upon the employee's employment in order for an employer's direction concerning the out-of-hours activity and conduct of an employee to fall within the scope of the employment and thus be lawful'. ${ }^{101}$ In this case, the Full Bench cited examples of where it was common for an employer to validly control employees' out of hours conduct (e.g., police and public servants) and explained the justifications for this, observing:

The nature of the employment in question, and the statutory, contractual and other legal obligations applicable to such employment, affect the scope of the employment and the capacity of the employer to issue lawful directions concerning outof-hours conduct. ${ }^{102}$

\footnotetext{
${ }^{90}$ Riverwood International Pty Ltd v McCormick. 2000. 177 ALR 193

${ }^{91}$ See, for example: Feldman, “Are Your Workplace Policies Contractually Binding?”; Longwill, "Could Your Employment Policies be Contractually Binding?"; Bruce, "Make Sure Your Handbook is NOT an Employment Contract"

92 Barker v Commonwealth Bank of Australia (2012) 296 ALR 706; Yousifv Commonwealth Bank of Australia (2010) 193 IR 212.

${ }^{93}$ Potter v WorkCover Corporation (2004) 133 IR 458, 475 [70].

${ }^{94}$ Adami v Maison De Luxe Ltd (1924) 35 CLR 143.

${ }^{95}$ King v Catholic Education Office (2014) 242 IR 249, 262 [27] ( 'King').

${ }^{96} R v$ Darling Island Stevedoring and Lighterage Company Ltd; ex parte Halliday and Sullivan (1948) 60 CLR 601, 621.

${ }^{97}$ Woolworths Limited v Brown (2005) 145 IR 285 ('Woolworths').

98 Woolworths Limited v Brown (2005) 145 IR 285, 294 [27].

${ }^{99}$ Woolworths Limited v Brown (2005) 145 IR 285, 300 [45].

${ }^{100}$ King v Catholic Education Office (2014) 242 IR 249, 262 [28].

${ }^{101}$ King v Catholic Education Office (2014) 242 IR 249, 263 [28].

${ }^{102}$ King v Catholic Education Office (2014) 242 IR 249, 263 [29].
} 
In King, it was found that a direction forbidding a teacher providing private transport to students out of hours was lawful and reasonable, due to the school's potential vicarious liability and possible reputational damage, given that it had been involved in allegations of sexual abuse of its students. In Kolodjashnij v Lion Nathan, the FWC considered when a workplace policy seeking to control employee behaviour out of hours may be reasonable:

\begin{abstract}
While not every policy adopted by an employer will necessarily be found to be reasonable, particularly in circumstances where that policy purports to constrain the activities of employees outside working hours, some such policies will have the necessary connection to the workplace to be upheld. Where the employer can make out a legitimate interest in the conduct of its employees outside work hours, a policy aimed at regulating that conduct and protecting the employer's legitimate interests will generally be found to be reasonable. ${ }^{103}$
\end{abstract}

In terms of the lawfulness of SM policies that seek to control employee Category 3 conduct outside work hours, it has been argued that such policies constitute lawful and reasonable directions because they protect an employer's reputation. ${ }^{104}$ This raises the question: do all employees have an obligation to protect their employer's reputation at all times, even when they are not at work?

\title{
The Rose v Telstra Test Applied To Category 3 Cases
}

Rose v Telstra is often cited as delimiting when an employer can control an employee's out of hours' conduct. In this case, Mr Rose, a Telstra employee, was involved in a physical altercation with another Telstra employee in a hotel in Tamworth, NSW, where they were both staying while on assignment for Telstra. Both employees were being paid a travel allowance by Telstra to cover their accommodation costs. The altercation occurred after both employees had finished work for the day. Neither employee was wearing a Telstra uniform at the time of the altercation, and neither was 'on-call'. However, the hotel owner was aware both men were Telstra employees, and it was reported that the incident was "well known at the Tamworth Telstra depot'. ${ }^{105}$ Mr Rose's employment was terminated by Telstra and he made a claim for unfair dismissal.

In determining whether there was a valid reason for Mr Rose's dismissal, the Commission observed that the shift in the nature of the employment relationship from the status-based paternalistic relationship of master and servant to one based on contract meant that an employer's ability to discipline an employee for conduct occurring outside working hours was curtailed. Following an extensive examination of the authorities concerning when conduct outside working hours can constitute a valid reason for dismissal, the Commission observed that for an employee's out of hours conduct to provide a valid reason for dismissal, the off-duty conduct must:
a) be likely to cause serious damage to the relationship between employer and employee; or
b) damage the employer's interests; or
c) be incompatible with the employee's duty as an employee.

In essence, the conduct complained of must be of such gravity or importance as to indicate a rejection or repudiation of the employment contract by the employee. ${ }^{106}$

The Commission found that Mr Rose's conduct did not constitute a valid reason for his dismissal. While Mr Rose's conduct was 'foolish':

\begin{abstract}
[E]mployers do not have an unfettered right to sit in judgment on the out of work behaviour of their employees. An employee is entitled to a private life. The circumstances in which an employee may be validly terminated because of their conduct outside work are limited. The facts of this case do not fall within those limited circumstances. ${ }^{107}$
\end{abstract}

Applying the test in Rose v Telstra to an employee's out of hours conduct on SM, clearly Category 1 conduct (disparaging an employer) is likely to damage the relationship between the employer and employee, be incompatible with the employee's contractual duty of fidelity and loyalty and also damage the employer's interests. Category 2 behaviour (harassment and intimidation of other employees) is also likely to be incompatible with employee's duty as an employee, as it may expose the employer to liability or affect relationships between employees at work. However, Category 3 behaviour on SM does not necessarily meet any of the Rose v Telstra criteria, unless it is accepted that all employees have a duty to protect their employer's

\footnotetext{
${ }^{103}$ Kolodjashnij v Lion Nathan [2009] AIRC 893, [52] ('Lion Nathan').

${ }^{104}$ Brown, "Privacy Concerns over Employer Access to Employee Social Media."; Pearson v Linfox Australia Pty Ltd [2014] FWC 446

[47].

${ }^{105}$ Rose v Telstra Corporation Limited. [1998] AIRC.3.

${ }^{106}$ Rose v Telstra Corporation Limited. [1998] AIRC.12.

${ }^{107}$ Rose v Telstra Corporation Limited. [1998] AIRC.18.
} 
reputation at all times. Thus, Category 3 behaviour may be said to 'damage the employer's interests' and/or be 'incompatible with (the employee's) duties as an employee.'

\section{Category 3 Conduct On SM}

In Australia, of the few Category 3 cases that have been litigated to completion, ${ }^{108}$ the issue of the employer's right to protect its reputation has not been directly addressed. One example is Singh v Aerocare ${ }^{109} \mathrm{Mr}$ Singh was an airline service agent with Aerocare who was terminated following a series of Facebook posts. The main one related to the sharing of a post by the radical Islamic group Hizb-ut Tahrir and adding the comment 'we all support ISIS'. Mr Singh's Facebook profile was conducted under a pseudonym and did not identify he was employed by Aerocare. His post came to the attention of Aerocare through other employees who were Facebook friends with Singh. Aerocare argued that the post demonstrated Mr Singh supported ISIS, and that this was a valid reason for his termination given the nature of his employment. Mr Singh argued that this post was sarcastic and that his other activity on SM clearly indicated he did not support ISIS. There was evidence in his other posts to support Mr Singh's claim.

The FWC found that the reason the employer had dismissed Mr Singh was that he supported ISIS, believing he posed a security risk. Because the evidence clearly showed he did not support ISIS, there was no valid reason for his dismissal. The Commission observed that, had the employer taken more care in its investigations, it would have discovered this.

The FWC observed that Mr Singh had clearly breached Aerocare's SM policy by making the post, and it did not matter that he had used a pseudonym or that his Facebook profile did not identify him as an employee. The relevant section of the SM policy provided:

Employees should be aware that their actions captured via images, posts, or comments can reflect that of our company. Employees must be respectful to the company, other employees, customers, partners, and competitors and are discouraged from publishing weblogs or other publications that are intended to, or may have the result of, causing harm to Aerocare. ${ }^{110}$

However, the Commission's decision does not make clear whether breach of the SM policy alone would have been sufficient to justify Mr Singh's dismissal. Given that Mr Singh was not a supporter of ISIS, whether simply making the post was a sufficient reason to justify dismissal was not an issue canvassed in detail by the Commission. While the issue of potential reputational damage to Aerocare was discussed by the Commission, it was analysed based on the harm that could have occurred had the post been true. It appears from the judgment that the post had not come to the attention of the relevant aviation authorities, police or media, and this may have influenced the Commission's observations regarding its consideration of the potential reputational harm to Aerocare.

Toll v Erikson establishes that employers may control employee behaviour on SM to protect their reputation even when the employee is no longer working for the employer. ${ }^{111}$ In this case, Mr Erikson was a member of a far right group. His employment with Toll had been terminated when it was discovered he had made false statements in his employment application about his prior criminal record and abandoned his employment following a criminal conviction. He was directed to return his Toll uniform, but did not do so. Instead, while wearing his uniform, he posted videos on the United Patriots Facebook page, claiming that (former federal politician) Sam Dastyari was a terrorist. Mr Erikson also claimed in the videos that he had been terminated for expressing these views. Toll sought orders under s 50 of the Fair Work Act that Erikson had breached a provision of an enterprise agreement relating to failure to return uniforms. It attached to this claim a claim for the tort of injurious falsehood, and sought an injunction ordering the return of uniforms and orders that he cease making posts on Facebook while wearing his Toll uniform. The Federal Circuit Court granted the injunction, ordering the return of the uniforms and restraining Mr Erikson from posting videos wearing his Toll uniform. The Court observed that:

A member of the public viewing the footage could reasonably conclude (and in fact did conclude) that the statements expressed by (Erikson) were either statements that Toll supported, or which were attributable to Toll. ${ }^{112}$

\footnotetext{
${ }^{108}$ For an example of a Category 3 case not involving an employee but a member of the armed services, see Chief of the Defence Force $v$ Gaynor [2017] FCAFC 41.

${ }^{109}$ Singh v Aerocare Flight Support Pty Ltd [2016] FWC 6286.

${ }^{110}$ Singh v Aerocare Flight Support Pty Ltd [2016] FWC 6286.[44].

${ }^{111}$ Toll Transport Pty Ltd v Erikson (2017) 276 IR 423.

${ }^{112}$ Toll Transport Pty Ltd v Erikson (2017) 276 IR 423, 442 [64].
} 
In Tiller v Relationships Australia, ${ }^{113} \mathrm{Mr}$ Tiller was a counsellor and relationship educator with Relationships Australia. He was also part of a men's focus group that supported men working in social services. The employer believed the men's focus group was promoting the idea that domestic violence was not a gender-based issue, and that Mr Tiller was circulating material from the men's focus group via his work email that appeared to endorse this view. Mr Tiller was also making posts on the men's focus group Facebook page that the employer believed were inconsistent with its policies about the gendered nature of domestic violence, forming the view that this was potentially damaging to its reputation. Following a discussion with Mr Tiller about these matters, he resigned. While the FWC found that Mr Tiller had not been dismissed by Relationships Australia, it gives little credence to the employer's arguments about Mr Tiller's views having a negative effect on its reputation:

\begin{abstract}
Whilst (the employee) is obliged to carry out his duties in accordance with the Family and Domestic Violence Policy and procedures, his Employment Agreement does not, on it terms, have the effect of denying him the freedom to hold personal views and beliefs that are at odds with RAWA's policies. ${ }^{114}$
\end{abstract}

\title{
Category 3 Behaviour In The 'Real World'
}

As there are few Australian cases dealing with the relationship between Category 3 employee behaviour on SM and employer reputational risk, the authors have examined case law concerning Category 3-type behaviour in the 'real world' and its relationship to reputational risk for employers. The following analysis is limited to employee conduct not directly related to their employment, but which may damage the employer's reputation if their connection to the employer is known.

Writing on this topic in 2000, McCallum noted that the control over 'real world' Category 3 conduct of ordinary or 'standard' employees was limited. ${ }^{115}$ Concerning what he termed professional employees, McCallum observed that 'no Australian precedents ... home in on the concept of corporate image, yet in some cases it hovers in the background'. ${ }^{116}$

Many of the 'real-world' cases dealing with employer responses to employee behaviour out of hours relate to criminal conduct by the employee. These cases involve employees in both the public and private sectors. In the case of public sector employees, there are often express statutory provisions granting the relevant authority the power to terminate an employee's employment due to a criminal conviction for a serious offence. ${ }^{117}$ It has been noted that statutory controls over the behaviour of public servants outside work tend to be more strict because of the need to maintain public confidence:

For this reason public service Acts and regulations have in some respects gone considerably beyond what would be countenanced by the implied contractual duty of an ordinary employee to serve his or her employer with good faith and fidelity — at least in so far as the regulation of an employee's private activities are concerned. ${ }^{118}$

However, it is still possible for public sector employees to challenge an employer's decision to terminate them based on a criminal conviction by arguing that the dismissal is unfair. ${ }^{119}$

Earlier cases involving out of hours criminal conduct by the employee indicated a connection was needed between the criminal conduct and the employee's duties. For example, in Hussein v Westpac Banking Corporation, a bank employee was convicted of fraud relating to his personal ANZ credit card use. ${ }^{120}$ The Industrial Relations Court found that the employer was entitled to dismiss him because there was a relevant connection between the conviction and his ability to do his job. His role required him to engage with customers, and for them to place their trust in him. The Court noted that not all criminal convictions would have the relevant connection to employment, observing 'a conviction on a drink-driving charge which occurred outside work hours would not be relevant to the employment of many people'. ${ }^{121}$

In some cases, the tribunals have considered the potential effect of the employee's criminal conviction on the employer's reputation combined with the effect of the employee's ability to perform their duties as constituting a valid reason for dismissal.

\footnotetext{
113 Tiller v Relationships Australia Western Australia Inc. [2018] FWC 5519.

114 Tiller v Relationships Australia Western Australia Inc. [2018] FWC 5519 [160].

115 McCallum, Employer Controls Over Private Life, 28.

116 McCallum, Employer Controls Over Private Life, 35.

117 See, for example Government Sector Employment Act 2013 (NSW) s 69. See also Public Service Act 1999 (Cth) s 13 , which requires an employee of the Australian Public Service to 'at all times behave in a way which upholds APS values and the integrity and good reputation of the APS'.

${ }^{118}$ McManus v Scott- Charlton. 1996. 70 FCR 16, 25. See also Pender, "Before the High Court."”

${ }^{119}$ For Victorian and Commonwealth public servants, this is available via the unfair dismissal provisions of the Fair Work Act. In New South Wales, for example, see Industrial Relations Act 1996 (NSW) ss 84 and 98.

${ }^{120}$ Hussein v Westpac Banking Corporation (1995) 59 IR 103.

${ }^{121}$ Hussein v Westpac Banking Corporation (1995) 59 IR 107.
} 
For example, in Hunt $v$ Coomealla Health Aboriginal Corporation, Mr Hunt worked for the Corporation as a trainee health practitioner. ${ }^{122}$ His job entailed disseminating information about domestic violence and engaging the Aboriginal community in strategies to counter domestic violence. The FWC found that his being charged with domestic violence offences against his partner constituted a valid reason for his dismissal because of the potential effect on the reputation of his employer and because it compromised Mr Hunt's credibility in the performance of his work.

Similarly, in cases concerning criminal convictions of public sector employees, a number of the decisions show the relevant tribunal considering both the effect on the employer's reputation, and the need for public faith in the employee's ability to perform their duties as being relevant to the validity of the dismissal. ${ }^{123}$

In other cases, a criminal conviction has been found to be a valid reason for dismissal where there is clear inconsistency between the employee's conduct and the corporate image the employer is attempting to promote. In Lion Nathan, the employee, a process worker for James Boags Brewery, a division of Lion Nathan, was charged with high-range drink driving and reported the charge to his employer, who dismissed him. Lion Nathan had a Responsible Drinking Policy, which governed its employees' behaviour out of hours, and advised employees they could be disciplined for driving while above the legal alcohol limit whether on company business or not. ${ }^{124}$ Lion Nathan had invested considerably in promoting itself as a responsible producer and marketer of alcohol. ${ }^{125}$ It submitted it was entitled to regulate alcohol-related behaviour of its employees out of hours that had 'the potential to adversely affect Lion Nathan's reputation and credibility as a producer and marketer of alcoholic beverages committed to promoting the responsible use of alcohol'. ${ }^{126}$ The employee argued that the employer's policy was too wide and therefore not a lawful and reasonable direction, as it sought to control employee behaviour even where there was a potential risk to reputation, with no actual damage demonstrated.

The Commission found that there was a valid reason for the employee's dismissal related to the employee's breach of the policy. It further found that the policy was a lawful and reasonable direction because of its connection to the employer's investment in its brand as a responsible producer and marketer of alcohol. Further, the employer did not have to demonstrate there was actual damage to its reputation - the potential for damage was sufficient. ${ }^{127}$

However, there have also been some cases involving out of hours criminal conduct by an employee, suggesting actual or potential damage to the employer's reputation generally may be sufficient to justify dismissal. In Wakim v Bluestar Global Logistics, Mr Wakim, the marketing manager for Bluestar, was dismissed following his conviction for sex offences against a child. ${ }^{128}$ The FWC found that the conviction was a valid reason for dismissal. Mr Wakim was described as a 'public figure', and so his conviction had attracted media attention. In addition, his crime was considered particularly abhorrent by the community. ${ }^{129}$ In this case, the Commission held that there will be a necessary connection between an employee's out of hours criminal conduct and the employee's employment if the conviction 'will in some way affect the employer's reputation or compromise the employee's capacity to perform his or her duties' ${ }^{130}$ This seems to indicate that the criminal conviction having an effect on the employer's reputation alone will be sufficient to justify dismissal; it may not need to impede the employee's ability to perform their role. In Deeth $v$ Milly Hill Pty Ltd, an apprentice butcher was dismissed after he was charged with being accessory after the fact to murder. ${ }^{131}$ The Commission found that there was a valid reason for the dismissal, and appears to have been strongly influenced by the potential association that people in the local community would make between the apprentice and the employer's business.

\footnotetext{
${ }^{122}$ Hunt $v$ Coomealla Health Aboriginal Corporation [2018] FWC 3743.

${ }^{123}$ Bercove v Hermes (1983) 74 FLR 315; $R$ v Teachers Appeal Board; Ex Parte Bilney (1983-1984) 6 IR 476; Corrective Services $v$ Danwer [2013] NSWIRComm 61; Evans v Industrial Relations Secretary (on behalf of Dept of Justice) [2018] NSWIR Comm 1075; Kathuria $v$ The Commonwealth of Australia as represented by the Commissioner of Taxation [2015] FWC 8553; Sandilands $v$ Industrial Relations Secretary (on behalf of Legal Aid NSW) [2018] NSWIRComm 1051.

${ }^{124}$ Kolodjashnij v Lion Nathan [2009] AIRC 893 [34].

${ }^{125}$ Kolodjashnij v Lion Nathan [2009] AIRC 893 [10]. For example, the company voluntarily imposed an alcohol limit on some of its beverages and contributed to alcohol research and organisations that provided services promoting responsible alcohol use.

${ }^{126}$ Kolodjashnij v Lion Nathan [2009] AIRC 893 [15].

${ }^{127}$ Kolodjashnij v Lion Nathan [2009] AIRC 893 [55]. Confirmed on appeal in Kolodjashnij v J Boag and Son Brewing Pty Ltd [2010] FWAFB 3258.

${ }^{128}$ Wakim v Bluestar Global Logistics [2016] FWC 6992.

${ }^{129}$ Wakim v Bluestar Global Logistics [2016] FWC 6992 [33].

${ }^{130}$ Wakim v Bluestar Global Logistics [2016] FWC 6992 [32].

${ }^{131}$ Deeth v Milly Hill Pty Ltd [2015] FWC 6422.
} 
Similarly, in the public sector, dismissals for criminal convictions have been upheld in more recent decisions even though there is no direct nexus between the nature of the employee's duties and the offence. Some examples include: Cooper v Australian Taxation Office, involving the dismissal of an ATO employee for acts of indecency against a person under the age of 16 years outside Australia, ${ }^{132}$ Hansen $v$ Secretary of the Department of Transport, in which a fleet service manager with the Roads and Maritime Service was dismissed following a conviction relating to the possession of child pornography on his personal computer $^{133}$ and Klazidis $v$ Commissioner of Police, in which a financial analyst with the NSW Police Service was dismissed following a conviction for affray arising out of an assault. ${ }^{134}$ In all three cases, the relevant tribunal was prepared to accept the serious nature of the offence alone as justifying the dismissal, even though there was no relevant connection between the offence and the employee's duties.

In 'real-world' cases involving less serious conduct by employees, it seems dismissal will be justified where the employee's conduct outside work impedes their ability to do their job ${ }^{135}$ or when the conduct exposes the employer to legal liability. ${ }^{136}$ The employer's potential or actual reputational risk alone has been held to justify dismissal where the employer can demonstrate risk of damage to an existing valuable commercial or community relationship. ${ }^{137}$ The authors were unable to find cases of 'realworld' conduct in this category where concern for employer reputation 'at large' was a reason justifying dismissal. In fact, in the recent case of Puszka v Ryan Wilks Pty Ltd, the FWC found that an employee's drunkenness at an after-work function involving the employer's client was not a valid reason for dismissal. ${ }^{138}$ The Commission commented that while '[t]he conduct of employees outside of work hours has increasingly become the subject of potential scrutiny by employers', ${ }^{139}$ a single act of drunkenness at an after-work function 'for which no serious risk to the reputation or viability of the employer's business could be established' did not justify dismissal. ${ }^{140}$

Therefore, in the case of 'real-world' Category 3 conduct, it seems employers need to establish a connection to the employee's ability to do their job or a clear incompatibility between the employee conduct and an image, brand, or commercial relationship that the employer is attempting to foster. Where the protection of the employer's reputation 'at large' has been accepted as a valid reason for dismissal, this has occurred only recently, and in the context of serious criminal conduct by the employee. The authors argue that the same standard should apply to Category 3 behaviour on SM.

Some employees, by dint of the nature of their employment, have an obligation to conduct themselves at all times in a manner that will not harm the reputation of their employer, even when they are not at work. Bartlett and Sterry argued that professional footballers fall into this category:

The employment conditions of a player are not simply to play football, but in addition to be an ambassador for his employer's club, the (relevant football code), the sponsors and the licensees. These diverse roles are reflected in the policies and agreements that bind the players. ${ }^{141}$

Most employees are not paid to be their employer's brand ambassadors in their personal time, and any SM policy requiring them to so act is not a lawful and reasonable direction. It is beyond the scope of the employee's obligations under their COE, in the absence of express contractual or statutory obligations requiring them to do so.

The authors suggest that, in determining whether a SM policy constitutes a lawful and reasonable direction, tribunals in Australia should consider adopting the 'proportionality' test proposed in McManus v Scott Charlton. In McManus v Scott Charlton, in discussing whether an employer direction relating to an employee's conduct outside working hours was reasonable, the Federal Court suggests a test of 'proportionality', involving balancing the employer's interests asserted against the level of intrusion of the direction into the employee's personal life. Based on this test, a SM policy that sought to control all employee conduct on SM out of hours for the purpose of protecting employer reputation generally would be considered disproportionate.

${ }^{132}$ Cooper $v$ Australian Taxation Office [2014] FWC 7551.

${ }^{133}$ Hansen $v$ Secretary of the Department of Transport [2016] NSWIRComm 1011.

${ }^{134}$ Klazidis v Commissioner of Police [2016] NSWIRComm 1014.

${ }^{135}$ Orr v The University of Tasmania (1957)100 CLR 526; Duncan v Community Connections (Vic) Ltd [2010] FWA 252.

${ }^{136}$ King v Catholic Education Office (2014) 242 IR 249; Roger Iannella v Engie Fire Services Australia Pty Ltd [2016] FWC 8389.

${ }^{137}$ Farquharson v Qantas Airlines Ltd (Australian Industrial Relations Commission, VP Lawler, SDP O'Callaghan, Commissioner

Raffaelli 10 August 2006); Fenton v Makesafe [2013] FWC 5639; Applicant v Employer [2015] FWC 506; Clarkin v Betchel Construction (Australia) Pty Limited [2017] FWC 1871.

${ }^{138}$ Puszka v Ryan Wilks Pty Ltd [2019] FWC 1132.

${ }^{139}$ Puszka v Ryan Wilks Pty Ltd [2019] FWC 1132 [61].

${ }^{140}$ Puszka v Ryan Wilks Pty Ltd [2019] FWC 1132.[62].

${ }^{141}$ Bartlett, "Regulating the Private Conduct of Employees," 103. 
However, a SM policy directed at protecting particular interests of the employer, similar to the Responsible Consumption of Alcohol Policy in the Lion Nathan case, would not be.

The authors further suggest that, where an employer seeks to enforce their SM policy, tribunals in Australia should adopt the pragmatic approach taken in Smith v Trafford Housing Trust ${ }^{142}$ that used an objective test to determine whether it was likely that the employee's comments on SM would be attributed to their employer.

The Trafford case is directly relevant to the Australian context because, unlike many of the United Kingdom decisions concerning employee behaviour on SM, the employee did not seek to argue he had been unfairly dismissed under the Employment Rights Act 1996 (UK), nor were the provisions of the European Convention on Human Rights engaged. ${ }^{143}$ The issue was solely whether the employee's Category 3 conduct on SM entitled the employer to exercise its contractual rights to demote him.

In this case, the employer demoted the employee for misconduct following two posts he had made on his personal Facebook wall opposing same-sex marriage in churches as 'an equality too far'. ${ }^{144}$ His Facebook page identified him as working for the Trafford Housing Trust, and his Facebook wall could be viewed by 'friends' and 'friends of friends'. ${ }^{145}$ The Trust claimed that these posts breached its Code of Conduct, which provided that 'Employees should not engage in any activities which may bring the Trust into disrepute, either at work or outside work', defined to include conduct on SM. ${ }^{146}$ The employer argued that the posts brought the Trust into disrepute because they created a 'real risk that readers (of the posts) would think that he was expressing views on the Trust's behalf'. ${ }^{147}$ Second, it argued that even if people did not believe he was expressing views on behalf of the Trust, the distress that might be caused to staff or even customers of the Trust could cause reputational damage to the Trust. It pointed to its public profile of respect for the diversity of its employees and clients, particularly its recent accreditation by an organisation that provided advice and support to LGBTQI people. The employee argued that the employer's decision to demote him was itself a breach of his employment contract because he had not engaged in misconduct.

The Court found that Mr Smith's posts did not constitute misconduct and, therefore, the employer was in breach of his contract for demoting him. Regarding arguments of reputational risk, the Court observed that no reasonable reader of his Facebook wall could rationally conclude the posts were made on behalf of the Trust given they were made in a personal capacity, and that Mr Smith used his Facebook wall 'as a medium for personal or social, rather than work-related, information or views'. ${ }^{148}$ This conclusion was drawn because other recent posts on Mr Smith's wall related to his breakfast choices, washing his motorcycle and results in the English football league. Concerning the argument that the expression of these views could cause distress to employees and clients of the Trust, the Court observed that it again could not 'envisage how any such loss of reputation would arise in the mind of a reasonable reader'. ${ }^{149}$ It was noted that the Trust encouraged diversity in recruitment, bringing the possibility that some employees might express views that 'however moderately expressed, may cause distress among the holders of deeply felt opposite views'. ${ }^{150}$ The authors argue that the approaches taken in these two cases represent a sensible approach to employer control of employee behaviour on SM in Category 3 cases.

\section{Conclusion}

The justification for SM policies attempting to control employee conduct in Category 3 is that they are necessary to protect the employer's interests and reputation, even if unrelated to the employee's employment. However, this assumes that all employees have a duty to maintain their employer's reputation, even when they are 'off the clock'. There are also some employees (e.g., Israel Folau) whose position and status within an organisation are such that it is clearly part of their employment contract to protect the employer's reputation at all times. However, this is not most of us.

To date in Australia, whether such policies constitute lawful and reasonable directions in these circumstances does not appear to have been directly tested. We have argued that not only is it unreasonable to be disciplined by an employer for views and

\footnotetext{
142 Smith v Trafford Housing Trust [2012] EWHC 3221 ( 'Trafford').

143 Smith v Trafford Housing Trust [2012] EWHC 3221 [7].

144 Smith v Trafford Housing Trust [2012] EWHC 3221 [1].

145 Smith v Trafford Housing Trust [2012] EWHC 3221 [29].

146 Smith v Trafford Housing Trust [2012] EWHC 3221 [23].

147 Smith v Trafford Housing Trust [2012] EWHC 3221 [56].

148 Smith v Trafford Housing Trust [2012] EWHC 3221 [57].

149 Smith v Trafford Housing Trust [2012] EWHC 3221 [62].

150 Smith v Trafford Housing Trust [2012] EWHC 3221.
} 
actions expressed outside work unconnected with employment, it is also chilling free speech and producing docile bodies. If individuals are never 'off the clock' and are unable to participate or perform online where social interaction is becoming increasingly integral to society, then an employer has enormous power to set the moral and ethical standards of behaviour of ordinary citizens by reason only of controlling their ability to earn a living.

Foucault tells us that the process of behaviour modification involves the three steps: 1) observational hierarchy, 2) normalising judgement, and 3) examination. We may not be able to do anything about surveillance and technology, but if such cases are deemed unreasonable for repercussions in the workplace then the process is disrupted and docile bodies are not formed. We can use surveillance theory then as a framework to argue that the protection of an employer's reputation cannot make reasonable the modification of behaviour by private companies. Employees may not be able to evade surveillance, but to participate in a private life they need to feel safe from ramifications in their ability to earn a wage.

Discipline of employees for Category 3 behaviour on SM is only justified where the employee's conduct outside work impedes their ability to do their job, or when the conduct exposes the employer to legal liability. Reputational risk should only be of concern when the employer can demonstrate a real risk of damage to a specific, valuable, commercial, or community relationship. The role of the law here is to provide a counter measure to over-zealous SM policies that create the impression that an employee is constantly observed, that the employer's standards are how they are to be judged, even when not at work, and that repercussions and examination will follow. Surveillance theory notes that all three processes are needed to conform and modify docile bodies. If employees feel safe that they will not suffer repercussions for speaking freely, despite the employer's omnipresent gaze, then this method of surveillance does not work. This can be done by the courts and tribunals starting to more clearly maintain the line between personal life and work life.

\section{Bibliography}

Abril, Patricia, Avner Levin and Alissa Del Riego. "Blurred Boundaries: Social Media Privacy and the Twenty-First-Century Employee.” American Business Law Journal 49, no 1 (2012): 63-124. https://doi.org/10.1111/j.1744-1714.2011.01127.x

Allmer, Thomas. Towards a Critical Theory of Surveillance in Informational Capitalism. New York: Peter Lang, 2012. https://doi.org/10.3726/978-3-653-01459-4

Bartlett, Glen and Ryan Sterry. "Regulating the Private Conduct of Employees." Australian and New Zealand Sports Law Journal 7, n. 1 (2012): 91-119.

Bentham, Jeremy and Laurence Lafleur. An Introduction to the Principles of Morals and Legislation. New York: Hafner Pub. Co, 1948.

Bland, Andrew and Sarah Waterhouse. "Legal Risk Management of Social Media in the Workplace." Employment Law Bulletin 9 April/May (2013).

Brown, Murray and Chris Dent. "Privacy Concerns over Employer Access to Employee Social Media." Monash University Law Review 43, no 3 (2017): 796-827.

Bruce, Stephen. "Make Sure Your Handbook is NOT an Employment Contract.” HR Daily Advisor, 2013. https://hrdailyadvisor.blr.com/2013/10/30/make-sure-your-handbook-is-not-an-employment-contract

Byrnes, Michael. "Social Media Policy Legitimate for Protection of Employer Interests.” Clayton Utz, 23 January 2014. https://www.claytonutz.com/knowledge/2014/january/social-media-policy-legitimate-for-protection-of-employer-interests

Byrnes, Michael and Katie Paull, "Personal Expression, Professional Pain: Social Media and the Workplace." In House Counsel 19, no 6-7 (2015): 76.

Cox, Mark and Joanne Knoth. "Australia: Why Your Workplace Needs a Social Media Policy.” Mondaq: Connecting Knowledge and People, 30 November 2016. http://www.mondaq.com/australia/x/548750/employee+rights+labour+relations/Why+your+workplace+needs+a+social+ media+policy

Crowden, Greg. "Why Destructive, Divisive Folau could no Longer be the Face of Rugby." The Sydney Morning Herald, 11 April, 2019. https://www.smh.com.au/sport/rugby-union/move-him-on-destructive-divisive-folau-can-no-longer-be-theface-of-rugby-20190411-p51d51.html

Deakin, Simon, David Gindis, Geoffrey Hodgson, Kainan Huang, and Katharina Pistor. "Legal Institutionalism: Capitalism and the Constitutive Role of Law.” Journal of Comparative Economics 45, no 1 (2017): 188-200.

https://doi.org/10.1016/j.jce.2016.04.005

Decent, Tom. "Rugby Australia Set to Sack Israel Folau for Anti-Gay Social Media Post." The Sydney Morning Herald, 11 April, 2019. https://www.smh.com.au/sport/rugby-union/rugby-australia-set-to-sack-israel-folau-for-anti-gay-socialmedia-post-20190411-p51dar.html 
Decent, Tom. "Folau Teammates 'Like’ Anti-Gay Post as Sponsor Qantas Backs RA Action.” The Sydney Morning Herald, 11 April, 2019. https://www.smh.com.au/sport/rugby-union/folau-teammates-like-anti-gay-post-as-sponsor-qantas-backsra-action-20190411-p51d6b.html

Deleuze, Gilles. "Postscript on the Societies of Control." October 59 (1992): 3-7. http://links.jstor.org/sici?sici=0162$2870 \% 28199224 \% 2959 \% 3 \mathrm{C} 3 \% 3$ APOTSOC $\% 3 \mathrm{E} 2.0 . \mathrm{CO} \% 3 \mathrm{~B} 2-\mathrm{T}$

Fair Work Commission. Annual Report 2017-2018-Access to Justice. Canberra, 2017. https://www.fwc.gov.au/annualreport-2017-18

Feldman, Dan. “Are Your Workplace Policies Contractually Binding?” HR Legal, 2015, https://hrlegal.com.au/are-yourworkplace-policies-contractually-binding

Forsyth, Anthony. "A Thin Wall of Privacy Protection, with Gaps and Cracks: Regulation of Employees' Personal Information and Workplace Privacy in Australia." In Protection of Employees' Personal Information and Privacy, edited by Roger Blanpain, 7-34. Netherlands: Kluwer Law International, 2014.

Foucault, Michel. Discipline \& Punish. Translated by Alan Sheridan. New York: Vintage Books, 1995.

Galic, Masa, Tjerk Timan and Bert-Jaap Koops. "Bethan, Deleuze and Beyond: An Overview of Surveillance Theories from the Panopticon to Participation.” Philosophy \& Technology 30, no 1 (2007): 9-37. https://doi.org/10.1007/s13347-0160219-1

Ghoshray, Saby. "Employer Surveillance Versus Employer Privacy: The New Reality of Social Media and Workplace Privacy." Northern Kentucky Law Review 40, no 3 (2013): 593-626.

Giles, Shaun. "Rugby Australia Terminates Israel Folau's Contract." ABC News, 17 May, 2019. https://www.abc.net.au/news/2019-05-17/israel-folau-sacked-over-social-media-posts/11090938

Haggerty, Kevin and Richard Ericson. "The Surveillant Assemblage.” British Journal of Sociology 51, no 4 (2000): 605-622. http://dx.doi.org/10.1080/00071310020015280

Hebblewhite, Nicole. "How to Draft an Effective Social Media Policy for your Organisation.” Mondaq: Connecting Knowledge and People, 7 February, 2017.

http://www.mondaq.com/australia/x/566152/employee+rights+labour+relations/How+to+draft+an+effective+social+medi a+policy+for+your+organisation

Henderson, Troy, Tom Swann and Jim Stanford. Under the Employer's Eye: Electronic Monitoring and Surveillance in Australian Workplaces. (Centre for Future Work, The Australia Institute, November 2018).

Hodgkinson, Sarah. "Canada: Why Your Business Needs A Social Media Policy." Mondaq: Connecting Knowledge and People, 24 April, 2014.

http://www.mondaq.com/canada/x/588204/Social+Media/Why+Your+Business+Needs+a+Social+Media+Policy

Kelly, Justine. “Disciplining Employees' Out-of-Hours Behaviour: A Blurred Line.” Internet Law Bulletin 19, no 10 (2017): 446-449.

https://advance.lexis.com/api/permalink/c2fc231fd13e4600a03fac321074566e/?context=1201008\&federationidp=G4VXS J53601

Koziol, Michael. “'Folau's Law': Coalition MPs Push for Bolder Action in a 'New Dawn' for Religious Freedom.” The Sydney Morning Herald, 29 May, 2019. https://www.smh.com.au/politics/federal/folau-s-law-coalition-mps-push-for-bolderaction-in-a-new-dawn-for-religious-freedom-20190529-p51s9m.html

Lam, Helen. "Social Dilemmas in the Employment Context.” Employee Relations: Bradford 38, no 3 (2016): $420-437$. http://dx.doi.org/10.1108/ER-04-2015-0072

Lieu, Johnny. “Australian Man Gets Himself Fired After Making Sexist Comments on Facebook.” Mashable, 1 December, 2015. https://mashable.com/2015/11/30/man-fired-sexism-australia/

Loeb, Jennifer. "Canada: Social Media Use and the Workplace." Mondaq: Connecting Knowledge and People, 7 December, 2018. http://www.mondaq.com/canada/x/762456/Social+Media/Social+Media+Use+And+The+Workplace

Longwill, Tim and Peta Willoughby, “Could Your Employment Policies be Contractually Binding?” Lexology, 2015. https://www.lexology.com/library/detail.aspx?g=241b73ba-ea92-4f22-a500-ffdc6ff6b5e7

Lovell, Jon, Ming-Yee Ma and Emilie Maddox. "Misconduct by Social Media — a Global Perspective." Ashurst, 1 May, 2016. https://www.ashurst.com/en/news-and-insights/legal-updates/misconduct-by-social-media-a-global-perspective/

Mark, David. "Israel Folau to Take Rugby Australia to Fair Work Commission over Contract Termination." ABC News, 6 June, 2019. https://www.abc.net.au/news/2019-06-06/israel-folau-sues-rugby-australia-for-breach-of-contract/11185064

Mark, David. "Israel Folau Says He Has a "Mission to Spread the Word of God as He Tries to Get His Job Back." ABC News, 29 August, 2019. https://www.abc.net.au/news/2019-08-29/israel-folau-addresses-rugby-australia-in-bold-jobplea/11461504 
Mattson, James. "Expressing an Opinion on Social Media: Free Speech or Employment Peril?” Internet Law Bulletin 20 , no 3 (2017): 50-52. https://advance.lexis.com/api/permalink/d56fcfda-a4f1-40d5-8e76$\underline{848 \mathrm{c} 75762 \mathrm{~d} 45 / \text { ? context }=1201008 \& \text { federationidp }=\mathrm{G} 4 \text { VXSJ53601 }}$

McCallum, Ronald. Employer Controls over Private Life. Sydney: UNSW Press, 2000.

Macinnis, Angus. “Australia: No Social Media Policy? 'Not Sufficient', Says Fair Work Australia.” Mondaq: Connecting Knowledge and People, 18 February, 2012.

http://www.mondaq.com/australia/x/164928/Unfair+Wrongful+Dismissal/No+social+media+policy+Not+sufficient\%20+ says+Fair+Work+Australia

McDonald, Paula and Paul Thompson. "Social Media(tion) and the Reshaping of Public/Private Boundaries in Employment Relations.” Journal of Management Reviews 18 (2016): 69-84. https://doi.org/10.1111/ijmr.12061

McIlroy, Thomas, "Australian Public Service Commission Social Media Guidance Angers Opposition and Activists." The Sydney Morning Herald, August 7, 2017. https://www.smh.com.au/public-service/australian-public-service-commissionsocial-media-guidance-angers-opposition-and-activists-20170807-gxr2j9.html

Meade, Amanda. "'Don't Say Anything Stupid': Social Media Minefield for Journalists and Nine Newspapers.” The Guardian, 29 March, 2019. https://www.theguardian.com/media/2019/mar/29/dont-say-anything-stupid-social-mediaminefield-for-journalists-at-nine-newspapers

Moore, Peter. "Social Media Risk Management." Risk Management Today October (2013): 288

O’Halloran, Paul. “The Rise of e-Misconduct in the Workplace.” Internet Law Bulletin 15, no 5 (2012): 90-92. https://advance.lexis.com/api/permalink/b11a4d7c065b4b9db542583f89349074/?context=1201008\&federationidp=G4V XSJ53601

O'Halloran, Paul. "When Can You Dismiss an Employee for Misuse of Social Media?" Internet Law Bulletin 17, no 7 (2014): 150-152. https://advance.lexis.com/api/permalink/3c54a39a-f38f-4a36-bfe429bfde79b6d9/?context=1201008\&federationidp=G4VXSJ53601

O’Rourke, Anne, Amanda Pyman, Julian Teicher and Bernadine van Gramberg. "Old Wine in New Bottles? Regulating Employee Social Media Use through Termination of Employment Law.” Common Law World Review 47, no 4 (2018): 248-271. https://doi.org/10.1177\%2F1473779518807155

Pender, Kieran. "Before the High Court: Comcare v Banerji: Public Servants and Political Communication." Sydney Law Review 41, no 1 (2019): (advance).

Rapaport, Pauline. "Social Media Policies and Unfair Dismissal.” Media and Arts Law Review 18, no 2 (2013): $75-87$. https://advance.lexis.com/api/permalink/3552d5726a654f4599bae19965a5b5a6/?context=1201008\&federationidp=G4VX $\underline{\text { SJ53601 }}$

Raper, Elizabeth and Phillippa Munton. "Recent Privacy Considerations Arising in the Workplace: Social Media and Limitations on Collection and use by Employers of Employee Generated Content." Workplace Review 6 (2015): 59-62. http://sites.thomsonreuters.com.au/journals/files/2015/09/WR-Vol-6-No-2-Contents.pdf

Razak, Iskhandar. "Israel Folau's Unfair Dismissal Case against Rugby Australia Set for Trial in February.” ABC News, 13 August, 2019. https://www.abc.net.au/news/2019-08-13/israel-folau-takes-rugby-australia-to-federal-court-oversacking/11407404

Reitz, Anders, Jan Rudolph and Philip M Berkowitz, ed. Social Media and Employment Law: An International Survey. Netherlands: Kluwer Law International, 2015.

Robinson, Georgina. "Rich New Contract Comes at a Cost for Israel Folau." The Sydney Morning Herald, 9 February, 2019. https://www.smh.com.au/sport/rugby-union/rich-new-contract-comes-at-a-cost-for-israel-folau-20190208-p50wgh.html

Rousseau, Jean-Jacques. The Social Contract. London: Penguin Books, 1968.

Scott, Zina. "Canada: Why Your Business Needs A Social Media Policy." Mondaq: Connecting Knowledge and People, 9 January 2019.

http://www.mondaq.com/canada/x/769990/Social+Media/Why+Your+Business+Needs+a+Social+Media+Policy

Sewell, Graham. “Organization, Employees and Surveillance.” In Routledge Handbook of Surveillance Studies, edited by Kirstie Ball, Kevin Haggerty and David Lyon, 303-312. London: Routledge, 2012.

Smith, Lincoln. "Employment Law and Social Media." Bulletin (Law Society of SA) 33, no 4 (2011): 26.

Stewart, Andrew. Stewart's Guide to Employment Law $6^{\text {th }}$ Edition. Annandale, NSW: The Federation Press, 2018.

The Age. "Minister Slams Geelong Grammar Teacher's 'Irresponsible' Anti-Vax Post," The Age, 27 February, 2018. https://www.theage.com.au/national/victoria/minister-slams-geelong-grammar-teacher-s-irresponsible-anti-vax-post20180227-p4z1xj.html

The Roar. "Israel Folau Issued Breach Notice, Has 48 Hours to Respond.” The Roar, 15 April, 2019. https://www.theroar.com.au/2019/04/15/israel-folau-issued-breach-notice-has-48-hours-to-respond/ 
Thinakaran, Ajantha. "How to Write a Social Media Policy.” Internet Law Bulletin 20, no 4 (2017): 70-74. https://advance.lexis.com/api/permalink/240bdd9bb32d45e2b8494408e6aa9ad2/?context=1201008\&federationidp=G4V XSJ53601

Thompson, Paul. "Fantasy Island: A Labour Process Critique of the 'Age of Surveillance'." Surveillance \& Society 1 , no 2 (2003): 138-151. https://doi.org/10.24908/ss.v1i2.3350

Thornthwaite, Louise. "Chilling Times: Social Media Policies, Labour Law and Employment Relations.” Asia Pacific Journal of Human Resources 54, no 3 (2016): 332-351. https://doi.org/10.1111/1744-7941.12074

Thornthwaite, Louise. "Social Media and Dismissal: Towards a Reasonable Expectation of Privacy?” Journal of Industrial Relations 60, no 1 (2018): 119-136. https://doi.org/10.1177/0022185617723380

Whitson, Rhiana. “Angela Williamson: Cricket Australia Sacking Saga Ends with Out-of-Court Settlement.” ABC News, 14 September, 2018. https://www.abc.net.au/news/2018-09-14/angela-williamson-reaches-out-of-court-settlement/10248832

Zuboff, Shoshana. The Age of Surveillance Capitalism: The Fight for a Human Future at the New Frontier of Power. New York: Public Affairs, 2019.

\section{Primary Legal Material}

\section{Australia}

Ambrose v Moolarban Coal Operations. 2014. FWC 3899.

Annetta v Ansett Australia. 2000. 98 IR 233.

Applicant v Respondent. 1998. AIRC 639.

Australian Tramway Employees' Association v Brisbane Tramways Company Limited. 1912. 6 CAR 34.

Board of Bendigo Regional Institute of Technical and Further Education v Barclay. 2012. 248 CLR 500.

Bowker; Coombe; Zwarts v DP World Melbourne Limited T/A DP World; Maritime Union of Australia, The Victorian Branch and Others. 2014. FWFCB 9227.

Byrnes v Treloar. 1997. 77 IR 332.

Campbell Qube Ports Pty Ltd. 2017. FWC 1211.

CFMEU v BHP Coal Pty Limited. 2014. 253 CLR 243.

Chief of the Defence Force v Gaynor. 2017. FCAFC 41

Colwell v Sydney International Container Terminals Pty Limited. 2018. FWC 174.

Commissioner of Railways (NSW) v O'Donnell. 1938. 60 CLR 681.

Dover-Ray v Real Insurance Pty Ltd. 2010. 204 IR 399.

Fair Work Act 2009 (Cth).

Fitzgerald v Smith. 2010. 204 IR 292.

Fussell v Transport for NSW/TA Transport for NSW. 2019. FWC 1182.

Goldman Sachs JB Were Services Pty Ltd v Nikolich. 2007. 163 FCR 62.

GrainCorp Operations v Markham. 2002. IR 253.

Gramotnev v Queensland University of Technology. 2015. 251 IR 448.

Industrial Relations Reform Act 1993 (Cth).

Klooger v Foodora Australia Pty Limited. 2018. FWC 6836.

Linfox Australia Pty Limited v Stutsel. 2012. 217 IR 52.

Little v Credit Corp Group Limited. 2013. FWC 964.

Little v Credit Corp. 2013. FWC 9642.

Lukazsewski v Capones Pizzeria Kyneton. 2009. AIRC 280.

McIntyre v Special Broadcasting Services Corporation T/A SBS Corporation. 2015. FWC 6768.

McKeith v Royal Bank of Scotland. 2016. 92 NSWLR 326.

McManus v Scott- Charlton. 1996. 70 FCR 16.

Natoli v Anglican Community Services t/a Anglicare. 2018. FWC 2180.

O'Keefe v William Muir's Pty Limited. 2011. FWA 5311.

Potter v WorkCover Corporation. 2004. 133 IR 458.

Rani v Limitless Ventures Tpscas Pty Limited. 2015. FWC 6429.

Re Broadmeadows Disability Services. 2011. FWA 4063.

Remmert v Broken Hill Operations. 2016. FWC 6036.

Renton v Bendigo Health Care Group. 2017. FWC 921.

Riverwood International Pty Ltd v McCormick. 2000.

Roberts v VIEW Launceston Pty Ltd as trustee for the VIEW Launceston Trust and Ors. 2015. FWC 6556. 
Rombola v Rail Commissioner. 2017. FWC 194.

Romero v Farstad Shipping (Indian Pacific) Pty Limited (2014) 231 FCR 403.

Rose v Telstra Corporation Limited. [1998] AIRC.

Selvachandran v Peterson Plastics. 1995. 62 IR 371.

Somogyi v LED Technologies Pty Limited. 2017. FWC 1966.

Starr v Department of Human Services. 2016. FWC 1460, 68.

Stutsel v Linfox Australia Pty Limited. 2011. 217 IR 28.

Toll (FGCT) Pty Limited v Alphapharm Pty Limited (2004) 219 CLR 165.

Vosper v Solibrooke Pty Limited. 2016. FWC 1168.

Westpac Banking Corporation v Wittenberg. 2016. 242 FCR 505.

Wilkinson-Reed v Launtoy. 2014. FWC 644.

\section{United Kingdom}

Robb v Green. 1895. 2 QB 315

Smith v Trafford Housing Trust. 2012. EWHC 3221.

Employment Rights Act 1996 (UK).

\section{USA}

National Labor Relations Act 1935, 29 U.S.C. \$§ 151-169. 